\title{
TERRAS DEVOLUTAS: A DESORDENADA CONSOLIDAÇÃO DA PROPRIEDADE TERRITORIAL NO BRASIL
}

\section{VACANT LANDS: THE UNORDED CONSOLIDATION OF TERRITORIAL PROPERTY IN BRAZIL}

\author{
Amanda de Campos Araújo \\ Pós-graduada em Direito Público \\ Pós-graduada em Direito Notarial e Registral \\ Faculdade Alfa de Almenara, Minas Gerais, Brasil \\ E-mail:amandacaaraujo@gmail.com
}

Recebido: 01/05/2020 - Aceito: 20/05/2020

\section{RESUMO}

O presente artigo relata a formação do território brasileiro e as causas da desordenada consolidação territorial no Brasil. Pretendeu-se resgatar os reflexos da colonização e a disciplina legal das terras devolutas para se estabelecer a razão da ocorrência de uma ocupação que favoreceu a desigualdade econômica e social. Pela análise da literatura sobre 0 assunto, percebeu-se que o objetivo da colonização - consistente em promover a rápida ocupação de uma vasta extensão territorial com a finalidade de se impedir a deflagração de conflitos para a definição de fronteiras - foi a causa principal de serem legitimadas pelo Estado, sem rigorosos critérios, as mais variadas formas de ocupação, processo esse agravado mais tarde pelos surgimento de interesses econômicos voltados para a exploração da terra, em detrimento de ocupações para mera subsistência, por parte das classes menos favorecidas.

PALAVRAS-CHAVE: Terras devolutas. Discriminação de terras. Ineficiência. Consolidação da propriedade. Ocupação desordenada do território brasileiro.

\section{ABSTRACT}

This article reports the formation of the brazilian territory and the causes of the disordered territorial consolidation in Brazil. It was intended to rescue the reflexes of colonization and the legal discipline of vacant lands to establish the reason for the occurrence of an occupation that favored economic and social inequality. From the 
analysis of the literature on the subject, it was perceived that the goal of colonization - to promote the rapid occupation of a vast territorial extension with the purpose of preventing the outbreak of conflicts for the definition of borders - was the main cause of being legitimized by the State, without rigorous criteria, the most varied forms of occupation, a process later aggravated by the emergence of economic interests aimed at the exploitation of the land, to the detriment of subsistence occupations by the less favored classes.

KEYWORDS: Vacant lands - land discrimination - inefficiency - property consolidation - disorganized occupation of the brazilian territory.

\section{INTRODUÇÃO}

É nítida a dificuldade atual enfrentada pelos órgãos estatais na promoção de políticas públicas voltadas para a regularização das terras devolutas. A inexistência de um controle efetivo de identificação e demarcação das terras ao longo dos anos ocasionou um vazio quanto aos registros e cadastros existentes para fins de se perquirir a origem das terras, resultando num desenfreado apossamento dos imóveis devolutos pelos particulares.

No presente artigo, pretendeu-se analisar as regulamentações a respeito das terras devolutas desde a colonização, incluindo-se a implantação do regime sesmarial, que representou a origem dos latifúndios até hoje existentes. Em seguida, foram analisadas as regulamentações acerca dos processos de discriminação das terras, para se compreender a atuação do Estado e suas consequências, bem como a relação desta com a atual desordenação territorial e com a má distribuição das terras, resultando no caótico quadro fundiário brasileiro atual.

Em seguida, verificou-se que as terras devolutas constituíram instituto capaz de legitimar ações fraudulentas e desarrazoadas em matéria de ocupação do território, resultando no favorecimento de interesses econômicos de empresas e particulares que se beneficiaram da ineficiência dos processos de identificação dessas terras, em detrimento de particulares integrantes de uma classe menos favorecida, que deveria, por viverem da exploração direta da terra, como meio de subsistência, por inúmeras gerações, ser considerada a legítima proprietária do território ocupado.

Acredita-se que um melhor conhecimento do processo histórico responsável pela configuração do atual quadro fundiário brasileiro possa permitir uma adequada 
compreensão dos elementos capazes de contribuir para a segurança e otimização do processo de regularização dos imóveis devolutos pelo Estado.

\section{DA DISCIPLINA LEGAL DAS TERRAS DEVOLUTAS}

O Brasil apresenta uma extensão territorial de 851 milhões de hectares. No ano de 2003, estimava-se que: 102 milhões de hectares constituíam área de conservação ambiental; 128 milhões tratavam-se de terras indígenas; 420 milhões eram cadastrados no INCRA - Instituto Nacional de Colonização e Reforma Agrária -; e 171 milhões constituíam terras devolutas. Das grandes propriedades cadastradas no INCRA (com mais de 15 módulos fiscais), mais de 70\% (120 milhões de hectares) eram consideradas improdutivas, conforme critérios instituídos pela Lei no 8.629/93 (OLIVEIRA, 2009, p. 29-30).

Analisando-se os dados, não se poderia pensar que pudesse ser tão excludente a política de terras em território nacional, nem tão significativas e sangrentas as disputas históricas que existiram e ainda existem na sociedade.

Embora se possa afirmar que o problema brasileiro não se trata de escassez de terra, buscar as razões exatas de um quadro tão peculiar em matéria de organização do território constitui tarefa complexa.

O quadro fundiário brasileiro existente na atualidade não pode ser considerado objeto de distorções ou desvios, tratando-se, inicialmente, do resultado da política governamental adotada quando da colonização e povoamento do território. Pelos objetivos do colonizador português, não se poderia esperar outra conduta capaz de nos legar uma estrutura fundiária saudável e com menos problemas para serem resolvidos na atualidade (SILVA, 1984, p. 55).

Ao tempo das ocupações do território brasileiro pelos indígenas, a terra era de uso coletivo, vista apenas como uma utilidade, não havendo interesse na repartição do território em propriedades particulares.

Com a vinda dos europeus, as terras descobertas eram consideradas propriedade da Monarquia. Houve a necessidade de ocupação do território conquistado pela Coroa Portuguesa, tendo sido concedido aos particulares o direito 
"supervisionado" de cultivo das terras - por meio das sesmarias ${ }^{1}$, as quais se destinavam à concessão de imensos latifúndios.

A aplicação desse instituto das sesmarias em Portugal era diferente. Neste, estas se tratavam de forma de se impelir o semeio de mantimentos em minifúndios, constituídos por casas e pardieiros abandonados ou destruídos (SILVA, 1984, p. 57). Isso porque, em Portugal, tinha-se uma concentração de terra nas mãos de todos e se precisava resolver o problema da escassez de alimentos, enquanto, no Brasil, tinha-se um imenso território que precisava ser preservado da cobiça alheia (ALVES, 1995, p. 37).

Inclusive, na lei de sesmarias portuguesa, editada pelo rei D. Fernando no ano de 1375, já se percebia uma ideia embrionária da função social da propriedade, vez que a produtividade constituía obrigação principal para a concessão das sesmarias em território português:

"1. ${ }^{\circ}$ ) os donos de terras ociosas seriam constrangidos a lavrá-las; $2 . .9$ ) caso não pudessem fazê-lo, por qualquer motivo justo, deveriam transferí-las a outrem, para que as herdades fossem "aproveitadas cumpridamente como for mister"; $3^{\circ}$ ) em caso de recusa ao cumprimento dessas duas primeiras obrigações (cultivar ou arrendar), a propriedade seria simplesmente confiscada, retornando ao bem comum." (ALVARENGA, 1979, p. 23)

O regime sesmarial implantado no Brasil, que constitui a origem dos latifúndios, foi se tornando ineficaz, inclusive pela dificuldade em se cumprir os requisitos estabelecidos pela Coroa, o que fez com que sesmeiros preferissem abandonar as concessões, com o objetivo de lavrar terras alheias, a salvo das obrigações impostas pelo Governo (LACERDA, 1960, p. 118).

Nas primeiras décadas do século XIX, era o regime sesmarial visto como um atraso na agricultura e no desenvolvimento econômico (VARELLA, 2005, p. 112), o que levou José Bonifácio de Andrada e Silva a arrancar de D. Pedro I a resolução de 17 de julho de 1822 (SILVA, 1984, p. 61), pondo termo a esse regime.

Suspenso o regime das sesmarias, instaurou-se um caos fundiário no Brasil, em virtude de uma vazio legislativo. Proliferou-se o sistema de aquisição da propriedade pela ocupação pura e simples (SILVA, 1984, p. 61), sendo esse período

\footnotetext{
1 O regime tratava-se de um costume consistente em se dividir, por sorteio, áreas das terras de lavrar
} da comuna chamadas de "sexmo", entre os munícipes, que as deveriam cultivar (LIMA, 1954, p. 11). 
tido como a revanche do lavrador contra os senhores da terra (GARCIA, 1958, p. 23). ${ }^{2}$

À época, a expressão "terras devolutas" já podia ser encontrada em algumas cartas de sesmarias e resoluções (JUNQUEIRA, 1976, p. 74), sempre com o significado de terras vazias, não ocupadas e, por esse fato, públicas, ou, ainda, no sentido de terras devolvidas à Nação, por terem incorrido em comisso (SILVA, 1984, p. 61).

Apenas com a Lei no 601, de 1850 (Lei de Terras), regulamentada pelo Decreto $\mathrm{n}^{0} 1.318$, de 30 de janeiro de 1854, é que surgiu a primeira disciplina sobre a possibilidade de reconhecimento jurídico do domínio das terras a particulares ${ }^{3}$, sendo que "a finalidade da elaboração da lei foi obter terras em que se fizesse a colonização por pessoas livres, de vez que, a esse tempo, já havia cessado o tráfico legal de escravos" (JUNQUEIRA, 1976, p. 78).

Com a nova legislação, pretendeu-se regulamentar todas as ocupações por particulares que cumprissem os requisitos da cultura efetiva da terra e do estabelecimento da morada habitual, ainda que se tratasse de sesmarias e concessões que incorreram em comisso ou, até mesmo, de ocupações sem títulos que a legitimassem. Segundo JUNQUEIRA

\begin{abstract}
"um pensamento constante, fixo, quase que uma obsessão: respeitar a todo custo a detenção daquele que, sem título dominial em ordem, estivesse em contato com o solo brasileiro (...). Se o ocupante com cultura e moradia aí estivesse sem título algum, sua ocupação seria respeitada, sua posse seria legitimada. Fosse o ocupante, com cultura e moradia, um antigo sesmeiro ou concessionário, que não houvesse cumprido as condições sob as quais Ihe havia sido concedido sua sesmaria ou concessão, sua ocupação seria respeitada e sua sesmaria ou concessão revalidada. Respeitada, é bom que se grave bem, a detenção de todo aquele que, sem títulos dominiais legítimos, estivesse ocupando o solo brasileiro, aí tendo cultura efetiva e morada habitual, fosse um simples posseiro, desamparado de qualquer título, ou fosse um sesmeiro ou concessionário relapso, tudo o mais que estivesse, naquele tempo, desocupado, desabitado, não cultivado, ermo, vago, e não reservado para o uso público, seria DEVOLUTO" (1976, p. 68).
\end{abstract}

\footnotetext{
2 É importante ressaltar que o reequilíbrio que se pretendeu quanto à questão da terra, com a extinção do regime das sesmarias, de fato, ficou a largo de grande parte da população à época, composta em sua maioria por escravos que não tinham sequer o domínio do próprio corpo. O próprio sistema econômico produzia um contingente de homens disponíveis que não se transformava nem em trabalhadores livres, nem em proprietários, por não disporem de meios para a exploração da terra (PEREIRA, 2003, p. 26).

${ }^{3} \mathrm{Na}$ verdade pretendia-se criar mecanismos que dificultassem a aquisição da terra, para que se tivesse um contingente de trabalhadores livres, formado essencialmente por imigrantes, que pudessem recompor a mão-de-obra que se encontrava escassa, pelo fim do tráfico negreiro de escravos (PEREIRA, 2003, p. 28).
} 
Havia, ainda, a obrigatoriedade de se declarar as áreas possuídas, o que pode ser considerado o embrião de um sistema de registro, embora com caráter meramente estatístico, o que se deu por meio dos títulos paroquiais, muito embora o Decreto regulamentador $n^{\circ}$ 1.318/544 tenha estipulado que essas certidões fornecidas pelo vigário da Paróquia não conferiam direitos aos possuidores (PEREIRA, 2003, p. 30).

Ainda de acordo com a Lei de Terras, as terras devolutas, na clara acepção de terras desocupadas, seriam objeto de venda. Não se poderia adquiri-las senão por título de compra (art. $\left.1^{\circ}\right)^{5}$, sendo impostas sanções para quem promovesse novas ocupações irregulares (art. $\left.2^{0}\right)^{6}$.

Inobstante a ampla regulamentação trazida pela legislação, não houve mecanismos efetivos que obrigassem os ocupantes a buscarem a regularização da titulação, permanecendo ineficiente a sistemática existente para a regularização da propriedade de terras públicas ${ }^{7}$.

$\mathrm{Na}$ transição entre o Império e a República foram publicados vários decretos que tiveram reflexos significativos quanto à questão fundiária. Dentre eles, o Governo Provisório instituiu os Decretos 451-B, de 31 de maio de 1890, regulamentado pelo Decreto ำ $955-\mathrm{A}$, de 05 de novembro de 1890 , que criou o Registro Torrens, sistema de registro que não era considerado obrigatório. Pouco tempo depois foi editado o Decreto 720, de 05 de setembro de 1890, que vigeu até o

\footnotetext{
${ }^{4}$ Art. 93. As declarações para o registro serão feitas pelos possuidores, que as escreverão, ou farão escrever por outrem em dois exemplares iguaes, assignando-os ambos, ou fazendo-os assignar pelo individuo, que os houver escripto, se os possuidores não souberem escrever.

Art. 94. As declarações para o registro das terras possuidas por menores, Indios, ou quaesquer Corporações, serão feitas por seus Paes, Tutores, Curadores, Directores, ou encarregados da administração de seus bens, e terras. As declarações, de que tratão este e o Artigo antecedente, não conferem algum direito aos possuidores.
}

5 Art. 1‥ Ficam prohibidas as acquisições de terras devolutas por outro titulo que não seja o de compra.

${ }^{6}$ Art. $2^{\circ}$ Os que se apossarem de terras devolutas ou de alheias, e nellas derribarem mattos ou thes puzerem fogo, serão obrigados a despejo, com perda de bemfeitorias, e de mais soffrerão a pena de dous a seis mezes do prisão e multa de $100 \$$, além da satisfação do damno causado. Esta pena, porém, não terá logar nos actos possessorios entre heréos confinantes.

7 "Mas a extensão territorial do País, a falta de técnicos para realizar o trabalho, a insuficiência de pessoal habilitado, tanto para o exercício da função de Juiz Comissário como para o exercício do cargo de Inspetor de Medição das terras vagas, o desinteresse pelas terras devolutas e sua consequente desvalorização fizeram com que, apesar dos objetivos da Lei n. 601 e de seu Regulamento (Decreto n. 1318, de 1854) permanecesse insolúvel o problema da propriedade territorial pública" (PEREIRA, 2003, p. 33). 
Código de Processo Civil de 1939, o qual trouxe uma reprodução dos princípios já vigentes (COSTA, 2017, p. 10)

Com a Constituição da República dos Estados Unidos do Brasil, de 24 de fevereiro de 1891, houve a transferência do controle das terras devolutas para os estados, tendo-se reservado à União apenas a porção do território "indispensável para a defesa das fronteiras, fortificações, construções militares e estradas de ferro federais" (art. 64).

A partir de então, a maioria dos Estados organizaram seus serviços com o fim de promover a discriminação das terras devolutas. Embora devessem observância aos limites traçados pela Constituição e pelas leis federais, na maioria das vezes os processos de privatização das terras devolutas ocorreram de forma desordenada, em virtudes das influências das elites agrárias, que fizeram prevalecer seus interesses particulares nesses processos, o que foi agravado pela carência de recursos técnicos e financeiros por parte dos entes estatais, na promoção das políticas de discriminação e titulação das terras públicas.

\section{DA DISCRIMINAÇÃO DAS TERRAS DEVOLUTAS}

O processo de discriminação tem por objetivo a separação das terras públicas das particulares. A ação discriminatória propicia que o Poder Público promova a identificação e arrecadação das terras devolutas, após o que deverá destiná-las ao cumprimento de sua função social, por meio da exploração racional do solo. Não pretende o Poder Público antepor seu domínio ao do particular, mas identificar suas terras, que com as destes são confundidas (MAIA, 1982, p. 96).

Foi também a já mencionada Lei oㅡ 601 (Lei de Terras), de 18 de setembro de 1850, que primeiro idealizou o processo discriminatório das terras devolutas de forma semelhante a que este se apresenta atualmente:

Art. 10. O Governo proverá o modo pratico de extremar o dominio publico do particular, segundo as regras acima estabelecidas, incumbindo a sua execução ás autoridades que julgar mais convenientes, ou a commissarios especiaes, os quaes procederão administrativamente, fazendo decidir por arbitros as questões e duvidas de facto, e dando de suas proprias decisões recurso para o Presidente da Provincia, do qual o haverá tambem para o Governo. 
Com o advento do Decreto ํo 1.318, de 30 de janeiro de 1854, que regulamentou a Lei de Terras, estabeleceu-se o procedimento discriminatório. Observa-se que o intuito da regulamentação sempre foi proteger as situações de posse consolidadas que se encontravam no território, o que se verificaria nas hipóteses de constatação da existência de cultura efetiva e morada habitual por parte do ocupante.

A esse respeito, segundo o referido Decreto, requerida a medição, o Juiz Comissário, que, conforme art. $30^{8}$, é nomeado pelo Presidente da Província, verificará a cultura efetiva e a morada habitual, para, em seguida, marcar a data da medição da terra (art. 37) ${ }^{9}$.

O procedimento abrange, segundo a regulamentação, a identificação da origem da terra (sesmaria, concessão ou simples ocupação pendente de regularização), a identificação dos limites e cálculos das áreas com a oitiva dos confrontantes e interessados e, por fim, a deliberação final pelo Presidente da Provincia, que, após ouvir o parecer do Delegado do Director Geral das Terras Publicas, daria a sua decisão. Se o julgamento do Presidente aprovar a medição, passa-se, em favor do posseiro, sesmeiro, ou concessionario o respectivo título de sua possessão, sesmaria, ou concessão.

Sobreveio o Decreto-lei ำ 9.760, de 05 de setembro de 1946, versando sobre os bens imóveis da União, o qual incumbiu ao Serviço de Patrimônio da União, representando a Fazenda Nacional, a discriminação das terras. O referido diploma dispunha sobre a discriminação administrativa e judicial das terras, legitimação e justificação de posse, alienação gratuita e onerosa das terras, arrendamento, expedição de títulos das terras devolutas e sobre o registro cadastral da propriedade pública (LACERDA, 1960, p. 906-929).

Criou-se, no âmbito da referida normatização, o Conselho de Terras da União (CUT), ao qual competia solver controvérsias que envolvessem imóveis da

\footnotetext{
${ }^{8}$ Art. 30. Obtidas as necessarias informações, os Presidentes das Provincias nomearão para cada hum dos Municipios, em que existirem sesmarias, ou outras concessões do Governo Geral, ou Provincial, sujeitas á revalidação, ou posses sujeitas á legitimação, hum Juiz Commissario de medições.

9 Art. 32. Feita a nomeação dos Juizes Commissarios das medições, o Presidente da Provincia marcará o prazo, em que deverão ser medidas as terras adquiridas por posses sujeitas á legitimação, ou por sesmarias, ou outras concessões, que estejão por medir, e sujeitas á revalidação, marcando maior ou menor prazo, segundo as circumstancias do Municipio, e o maior ou menor numero de posses, e sesmarias sujeitas á legitimação, e revalidação, que ainda existirem.
} 
União (arts. $7^{\circ}$ e $8^{\circ}$ ), e dar pareceres, quando solicitado, sobre processos de reserva de terras devolutas, além de possuir atribuição de órgão consultivo do Ministro da Fazenda.

O processo discriminatório poderia ocorrer na instância administrativa (ou de conciliação) e, quando esta não se efetivasse, na instância judicial ou contenciosa (art. 21) ${ }^{10}$. A fase administrativa seria dispensada caso a Fazenda Nacional constatasse ser esta ineficaz (parágrafo único) ${ }^{11}$.

O Decreto-lei no 9.760/46 foi revogado pela Lei 3.081, de 22 de dezembro de 1956, que aboliu o processo discriminatório administrativo, passando a existir apenas o processo discriminatório contencioso, tanto para a União, quanto para os Estados e Municípios (SILVA, 1984, p. 70).

Tanto o processo discriminatório administrativo quanto o judicial são objeto de críticas. O primeiro é reputado ineficaz, porque não se encontra isento de apreciação por parte do Judiciário (SILVA, 1984, p. 71), além de sujeitar os possuidores de terras ao arbítrio dos funcionários do Estado, parte e juiz da discriminação e, também, por findar-se com um despacho homologatório sem força executiva (JUNQUEIRA, 1942, p. 104). O segundo, pelas dificuldades processuais normais, que implicam a obediência a prazos, recursos e expedientes protelatórios, sem previsão de deslinde em tempo razoável, a fim de atender a necessidades como a reforma agrária e colonização (SILVA, 1984, p. 71).

No âmbito da Lei 3.081/56, havia três fases para a ação discriminatória (art. $\left.1^{\circ}\right)^{12}$.

A primeira, denominada "preliminar", é eminentemente administrativa, referindo-se ao chamamento dos interessados para a apresentação dos títulos de propriedade. Embora essa fase não admitisse contestação, os interessados, além de exibirem seus títulos, geralmente apresentavam objeções, retardando a conclusão da discriminação. Muitos juízes entendiam necessário promover a citação pessoal

\footnotetext{
${ }^{10}$ Art. 21. Desdobra-se em duas fases ou instâncias o processo discriminatório, uma administrativa ou amigável, outra judicial, recorrendo a Fazenda Nacional à segunda, relativamente àqueles contra quem não houve surtido ou não puder surtir efeitos a primeira.

11 Parágrafo único. Dispensar-se-á, todavia, a fase administrativa ou amigável, nas discriminatórias, em que a Fazenda Nacional verificar ser a mesma de todo ou em grande parte ineficaz pela incapacidade, ausência ou conhecida oposição da totalidade ou maioria dos interessados.

${ }^{12}$ Art. $1^{\circ}$ Compete à União, aos Estados e Municípios a ação discriminatória, para deslinde das terras de seu domínio, inclusive das terras situadas nas zonas indispensáveis à defesa do país, a que aludem o artigo 180 da Constituição Federal e a Lei o 2.597, de 12 de setembro de 1955. O processo constará de três fases: a preliminar, de chamamento à, instância e exibição dos títulos de propriedade; a contenciosa, que finaliza pelo julgamento do domínio e a demarcatória.
} 
de todas as pessoas encontradas na área objeto de discriminação, o que fez com que muitas ações tramitassem por décadas (MACHADO, 2002, p. 128).

$\mathrm{Na}$ segunda, denominada "contenciosa", discutia-se a validade dos títulos impugnados pela Fazenda Pública na primeira fase, culminando na sentença que reconhecia o domínio particular ou público e, se fosse o caso, a identificação geodésica da terra.

A terceira fase, denominada "demarcatória", tratava-se da execução da sentença, extremando-se o domínio público do particular.

O processo administrativo foi restaurado apenas com o Estatuto da Terra (Lei no 4.504, de 30 de novembro de 1964), no âmbito federal. Na ocasião, a União promoveu, com êxito, inúmeras discriminatórias, principalmente na área da fronteira agrícola dos Territórios Federais (COSTA, 2000, p. 128).

O art. 11, § 1013, desse diploma, previu a possibilidade da celebração de convênios entre o INCRA e os Estados, com o objetivo de realização de discriminação de terras devolutas, o que constituiu mecanismo importante à facilitação do procedimento de discriminação de terras.

Com o advento da Lei $n^{\circ}$ 6.383, de 07 de dezembro de 1976, que dispõe sobre o processo discriminatório de terras devolutas da União, houve previsão expressa de que a legitimidade ativa para o processo discriminatório pertence ao INCRA - Instituto Nacional de Colonização e Reforma Agrária -, conforme art. 18, que investe essa autarquia de poderes de representação do ente público, poderes esses também previstos no art. 11, do Estatuto da Terra.

A Lei no 6.383/76 aplica-se também às terras devolutas estaduais, conforme disposto em seu art. $27^{14}$, respeitando a autonomia dos Estados membros, no que couber, prevendo também a possibilidade de celebração de convênios entre estes e o INCRA. Os Estados membros devem seguir a disciplina do procedimento judicial

\footnotetext{
${ }^{13} \S 1^{\circ}$ Através de convênios, celebrados com os Estados e Municípios, iguais poderes poderão ser atribuídos ao Instituto Brasileiro de Reforma Agrária, quanto às terras devolutas estaduais e municipais, respeitada a legislação local, o regime jurídico próprio das terras situadas na faixa da fronteira nacional bem como a atividade dos órgãos de valorização regional.

${ }^{14}$ Art. 27 - O processo discriminatório previsto nesta Lei aplicar-se-á, no que couber, às terras devolutas estaduais, observado o seguinte:

I - na instância administrativa, por intermédio de órgão estadual específico, ou através do Instituto Nacional de Colonização e Reforma Agrária - INCRA, mediante convênio;

II - na instância judicial, na conformidade do que dispuser a Lei de Organização Judiciária local.
} 
previsto nessa Lei, porquanto Ihes é vedado legislar sobre Direito Processual, bem como sobre Direito Agrário.

Esse diploma normativo trouxe procedimentos inovadores, ao prever, no âmbito administrativo, a descentralização do processo discriminatório por Comissões Especiais, o que permitiria uma maior abrangência de áreas e também uma maior celeridade na tramitação. No âmbito judicial, previu: a adoção do procedimento sumaríssimo, conforme arts. 275 a 281 do antigo CPC; a possibilidade de citação por edital; o efeito apenas devolutivo do recurso, possibilitando a execução provisória da sentença; o caráter prejudicial e preferencial do processo.

Disciplinou também o instituto da legitimação de posse, atribuindo a "Licença de Ocupação", com direito a acesso aos financiamentos concedidos pelo Sistema Nacional de Crédito Rural, àqueles que comprovassem o animus de habitação e fixação em caráter permanente em área de até cem hectares, com a exploração regular da terra de forma pessoal ou familiar. A Licença de Ocupação terá o prazo de 04(quatro) anos, findo o qual o beneficiário terá preferência na aquisição da terra, pelo valor histórico da terra nua ${ }^{15}$.

Deve-se ressaltar, também, que o Estatuto da Terra prevê o instituto da regularização de posse ou ocupação (art. 97) ${ }^{16}$, que decorre da discriminatória e constitui forma de se regularizar uma ocupação que não preencheu os requisitos necessário para a legitimação de posse disciplinada pela Lei 6.383/76.

O procedimento administrativo, na Lei 6.383/76, é dividido em quatro fases.

\footnotetext{
${ }^{15}$ Art. 29 - O ocupante de terras públicas, que as tenha tornado produtivas com o seu trabalho e o de sua família, fará jus à legitimação da posse de área contínua até 100 (cem) hectares, desde que preencha os seguintes requisitos:

I - não seja proprietário de imóvel rural;

II - comprove a morada permanente e cultura efetiva, pelo prazo mínimo de 1 (um) ano.

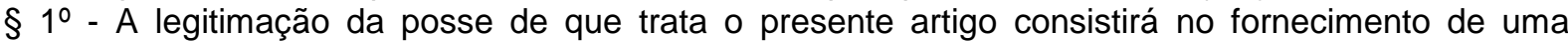
Licença de Ocupação, pelo prazo mínimo de mais 4 (quatro) anos, findo o qual o ocupante terá a preferência para aquisição do lote, pelo valor histórico da terra nua, satisfeitos os requisitos de morada permanente e cultura efetiva e comprovada a sua capacidade para desenvolver a área ocupada.

$\S 2^{\circ}$ - Aos portadores de Licenças de Ocupação, concedidas na forma da legislação anterior, será assegurada a preferência para aquisição de área até 100 (cem) hectares, nas condições do parágrafo anterior, e, o que exceder esse limite, pelo valor atual da terra nua.

16 Art. 97. Quanto aos legítimos possuidores de terras devolutas federais, observar-se-á o seguinte: I - o Instituto Brasileiro de Reforma Agrária promoverá a discriminação das áreas ocupadas por posseiros, para a progressiva regularização de suas condições de uso e posse da terra, providenciando, nos casos e condições previstos nesta Lei, a emissão dos títulos de domínio;

II - todo o trabalhador agrícola que, à data da presente Lei, tiver ocupado, por um ano, terras devolutas, terá preferência para adquirir um lote da dimensão do módulo de propriedade rural, que for estabelecido para a região, obedecidas as prescrições da lei.
} 
$\mathrm{Na}$ primeira, denominada "preliminar", promove-se a caracterização do perímetro, mediante memorial descritivo da área, aproveitando-se de acidentes naturais de fácil constatação. Nessa fase, identifica-se as propriedades e ocupações localizadas no perímetro demarcado, bem como as propriedades e posses confinantes, por meio do levantamento prévio das titulações existentes nas Serventias Imobiliárias, dados esses que serão confrontados com as declarações de propriedade apresentadas. Faz-se também o levantamento das benfeitorias, manifestações de cultura efetiva e morada permanente, apurando-se a existência de eventuais concessões feitas pelos poderes públicos nessa área. A partir de todos os dados levantados, a Comissão Especial do INCRA $^{17}$ deliberará acerca da pertinência de se deflagrar o processo discriminatório (MACHADO, 2002, p. 129).

A instauração do processo discriminatório é comunicada ao Registro de Imóveis da circunscrição a que estiver inserida a área, o qual deverá abster-se de praticar quaisquer atos com relação à gleba, sem o prévio conhecimento do Presidente da Comissão.

$\mathrm{Na}$ segunda fase, convoca-se os interessados, por edital, para apresentarem títulos, documentos e informações de interesse ${ }^{18}$, podendo, inclusive, indicar testemunhas, no prazo de sessenta dias. Realiza-se a avaliação desses documentos, identificando cadeias dominiais e reconhecendo títulos legítimos e posses legitimáveis, apurando-se, ao final, as áreas desocupadas.

A terceira fase caracteriza-se pela análise dos documentos e julgamento (art. $\left.7^{0}\right)^{19}$.

A quarta, pelo levantamento geodésico e topográfico das terras objeto de discriminação, ao fim da qual se determinará a demarcação das terras devolutas.

\footnotetext{
17 Art. $2^{\circ}$ - O processo discriminatório administrativo será instaurado por Comissões Especiais constituídas de três membros, a saber: um bacharel em direito do Serviço Jurídico do Instituto Nacional de Colonização e Reforma Agrária - INCRA, que a presidirá; um engenheiro agrônomo e um outro funcionário que exercerá as funções de secretário.

18 Art. $4^{\circ}$. (...)

$\S 1^{0}$ - Consideram-se de interesse as informações relativas à origem e seqüência dos títulos, localização, valor estimado e área certa ou aproximada das terras de quem se julgar legítimo proprietário ou ocupante; suas confrontações e nome dos confrontantes; natureza, qualidade e valor das benfeitorias; culturas e criações nelas existentes; financiamento e ônus incidentes sobre o imóvel e comprovantes de impostos pagos, se houver.

19 Art. 7ํ. Encerrado o prazo estabelecido no edital de convocação, o presidente da Comissão Especial, dentro de 30 (trinta) dias improrrogáveis, deverá pronunciar-se sobre as alegações, títulos de domínio, documentos dos interessados e boa-fé das ocupações, mandando lavrar os respectivos termos.
} 
Concluídos os trabalhos demarcatórios, o Presidente da Comissão Especial mandará lavrar um termo de encerramento, o qual conterá: o mapa da área discriminada; o rol de terras devolutas apuradas; a descrição dos acordos realizados; a relação das áreas com titulação transcrita no Registro de Imóveis, cujos presumidos proprietários ou ocupantes não atenderam ao edital de convocação ou à notificação (artigos 4ำ e 10 desta Lei); o rol das ocupações legitimáveis e das propriedades reconhecidas; e a relação dos imóveis cujos títulos suscitam dúvidas.

As terras devolutas apuradas serão arrecadadas por meio de portaria do Presidente do INCRA ou autoridade delegada que, no mesmo ato, poderá aprovar o procedimento e promover a extinção da Comissão Especial.

Caberá ao Procurador Federal requerer o registro perante a Serventia Imobiliária, mediante a apresentação do ato de arrecadação, da publicação no Diário Oficial da União e da planta e memorial descritivo da área arrecadada.

O processo judicial, que tramitará na Justiça Federal (parágrafo único, do art. 19), será utilizado nas hipóteses em que o processo administrativo for ineficaz, contra os interessados que não atenderem ao edital de convocação ou à notificação, ou na hipótese de, após o início do processo discriminatório, se alterarem as divisas da área discriminada, o que configura, inclusive, atentado.

\section{DA INEFICIÊNCIA DO PROCESSO DE DISCRIMINAÇÃO DE TERRAS DEVOLUTAS}

A breve historiografia acerca das terras devolutas e do processo discriminatório nos permite compreender que, de longa data, há minuciosa disciplina acerca desses institutos. Porém, este jamais foi capaz de alcançar os efeitos esperados e desejados.

Historicamente, preocupou-se o colonizador em incentivar o alargamento das fronteiras, o povoamento do solo pátrio e a produção, o que se deu por meio da concessão de extensos latifúndios (SILVA, 1984, p.75). A ocupação deveria se dar de forma célere e não havia, à época da colonização, um número significativo de pretensos ocupantes, o que justificava a concessão de imensas glebas a poucos interessados. Houve também certa omissão quanto à ocupação ordenada do solo, o 
que implicou a necessidade de que fossem regularizadas milhares de ocupações, sem uma rigorosa análise da origem dessas.

Ao invés de as terras devolutas servirem aos Poderes Públicos em grandes projetos em benefício da coletividade, objetivando a redução direta das desigualdades na distribuição de terras do país ${ }^{20}$, o que ocorreu foi uma enorme prevalência dos interesses de poucos atores usurpadores do patrimônio devoluto.

A organização do território na atualidade é decorrente da forma em que se deu a colonização, e as regulamentações existentes não foram capazes de superar os costumes jurídicos que se instauraram na sociedade.

A atuação estatal na identificação das terras devolutas cinge-se, basicamente, à prática da titulação aos indivíduos que promovem, ainda hoje, a ocupação do território e que querem adquirir a propriedade, em lugar de se utilizar a discriminação como ponto de partida (MACHADO, 2002, p. 130), para a arrecadação de grandes glebas que possibilitariam uma larga atuação estatal em prol da coletividade, com a distribuição justa e igualitária da terra.

E esse processo das ocupações, na medida em que foi se intensificando, gerou inúmeros conflitos de interesses, sobretudo entre as pequenas ocupações de

\footnotetext{
20 Não pode o Poder Público manter terras em seu domínio, a menos que seja para atender às finalidades contempladas no Estatuto da Terra, conforme art. 10, desse diploma normativo:

Art. 10. O Poder Público poderá explorar direta ou indiretamente, qualquer imóvel rural de sua propriedade, unicamente para fins de pesquisa, experimentação, demonstração e fomento, visando ao desenvolvimento da agricultura, a programas de colonização ou fins educativos de assistência técnica e de readaptação.

$\S 1^{\circ}$ Somente se admitirá a existência de imóveis rurais de propriedade pública, com objetivos diversos dos previstos neste artigo, em caráter transitório, desde que não haja viabilidade de transferi-los para a propriedade privada.

$\S 2^{\circ}$ Executados os projetos de colonização nos imóveis rurais de propriedade pública, com objetivos diversos dos previstos neste artigo, em caráter transitório.

$\S$ 3ํ Os imóveis rurais pertencentes à União, cuja utilização não se enquadre nos termos deste artigo, poderão ser transferidos ao Instituto Brasileiro de Reforma Agrária, ou com ele permutados por ato do Poder Executivo.
}

Art. 10. O Poder Público poderá explorar direta ou indiretamente, qualquer imóvel rural de sua propriedade, unicamente para fins de pesquisa, experimentação, demonstração e fomento, visando ao desenvolvimento da agricultura, a programas de colonização ou fins educativos de assistência técnica e de readaptação.

$\S 1^{\circ}$ Somente se admitirá a existência de imóveis rurais de propriedade pública, com objetivos diversos dos previstos neste artigo, em caráter transitório, desde que não haja viabilidade de transferi-los para a propriedade privada.

$\S 2$ ํㅡㄹ Executados os projetos de colonização nos imóveis rurais de propriedade pública, com objetivos diversos dos previstos neste artigo, em caráter transitório.

$\S 3^{\circ}$ Os imóveis rurais pertencentes à União, cuja utilização não se enquadre nos termos deste artigo, poderão ser transferidos ao Instituto Brasileiro de Reforma Agrária, ou com ele permutados por ato do Poder Executivo. 
minifúndios para subsistência e as grandes ocupações de latifúndios em defesa de interesses econômicos. É nesse contexto que se deve considerar o fenômeno da desterritorialização dos camponeses como uma das causas marcantes da desordem territorial nacional.

Historicamente, gerações inteiras viveram do cultivo da terra, no âmbito da agricultura familiar, plantando pequenas lavouras, criando seus animais para fornecimento de insumos e matérias-primas, e extraindo da natureza o que lhes era necessário para a sobrevivência. Esses camponeses, contudo, perderam suas posses, na maioria das vezes em virtude da atuação da elite agrária ou de grandes empresas em seu processo de expansão de produção.

Nas divisões geográficas em que ainda hoje se verifica grande extensão territorial, com baixa densidade demográfica, como no Amazonas e no Pará, esse fenômeno da desterritorialização dos camponeses ainda se encontra no auge do conflito, não sendo incomum deparar-nos com uma enxurrada de noticiários sobre o assunto. Em outras regiões, nota-se apenas resquícios desse momento conturbado de conflitos pela terra, muitas vezes apaziguado, outras vezes em discussão em processos infindáveis na justiça.

As terras devolutas constituíram instituto capaz de legitimar ações fraudulentas e desarrazoadas em matéria de ocupação de todo o território, em maior ou menor grau, a depender das condições locais. A venda de terras devolutas sempre constituiu fontes de escândalos e injustiças, em que os protegidos conseguem comprar terras ocupadas por terceiros humildes e desprotegidos (GARCIA, 1958, p. 165).

O posseiro, quase sempre, apenas após a efetivação da transação é que descobre que aquela terra que desbravou e cultivou foi vendida para terceiro que jamais ali pisou e que, em virtude da descoberta tardia, nada mais poderá fazer no âmbito administrativo (GARCIA, 1958, p. 165).

Em Minas Gerais, logo no início do regime republicano, foi regulamentada a questão das concessões das terras devolutas. Ocorre que não houve um efetivo plano colonizador com normas técnicas e agronômicas que fossem capazes de promover a fixação do homem na terra e de proporcionar meios de imprimir ao seu trabalho uma finalidade social, isenta de injunções perniciosas e do jogo do poderio econômico (MARCÍLIO, 1961, p. 124). 
Os latifundiários, mesmo sem preencher os requisitos legais, apressaram-se em requerer concessões imensas para transformá-las em grandes negócios, tudo em desrespeito aos legítimos direitos dos ocupantes, que tinham seus casebres destruídos e culturas invadidas (MARCÍLIO, 1961, p. 124).

Para ilustrar, pertinente noticiar um estudo realizado no norte de Minas Gerais, na região originária de Grão Mogol, que atualmente abrange também as comarcas de Porteirinha, Salinas, Francisco Sá e Montes Claros.

COSTA explica que, alijando inúmeros camponeses de suas moradas e da terra que, por gerações, Ihes fornecia o sustento, na primeira metade do século $X X$, sobretudo nas décadas de 20 e 30, predominou a grilagem judicial, ocasionada por processos de divisão e demarcação das terras propostos por integrantes da elite agrária local. Tais processos visaram o reconhecimento de propriedades de fazendas que, muitas das vezes, nem existiam (2017, p. 2-3).

A partir da década de 60, a grilagem persistiu com projetos estatais instalados no Norte de Minas, por meio das agências RURALMINAS E SUDENE que, também associadas com elites locais e empresas produtoras de eucalipto, aplicaram fortemente a política de favorecimento, em detrimento daqueles que, por inúmeras gerações, ocuparam e viveram dos usos da terra (COSTA, 2017, p. 2-3).

Inclusive, havia casos em que muitas glebas ocupadas por geraizeiros foram adjudicadas a grileiros que, após providenciarem a titulação da terra em seu nome perante o Estado, beneficiavam-se de posterior venda de parte dessas mesmas terras aos primeiros, conforme histórias narradas por Dona Joana e seu Joaquinzão (casal à época com, respectivamente, 77 e 82 anos, que vivia em uma grota na localidade denominada "Curralinho", em Justinópolis/MG) ${ }^{21}$, ou Dona Vicença (à

\footnotetext{
21 "Dona Joana contou que seu pai se preocupou em garantir a permanência dos filhos na terra, "quando a gente morrer tem que deixar os filhos autorizados", quer dizer, com alguma garantia de permanência na terra. Mesmo vivendo em um período em que havia muitas terras livres, ele comprou 16 alqueires de "Joaquim Beltrão da Silva" - um dos maiores beneficiários pela grilagem judicial das terras na Fazenda Ribeirão das Piabanhas e em outros processos de divisão que tramitaram na Comarca de Grão Mogol - "ele vendia e comprava terra pra todo lado, este homem tinha fazendas", confirmou seu Joaquinzão. O fazendeiro "Joaquim Beltrão da Silva" pode comprar e vender terras aos camponeses porque foi beneficiado com uma área imensa de terras devolutas, as mesmas terras usadas também em regime de uso comum pelos geraizeiros. O rentista "Joaquim Beltrão da Silva" por pertencer a este grupo privilegiado, exerceu as atribuições de arbitrador, escrivão, tabelião substituto, testemunha e suposto representante legal de camponeses nos processos, o que the permitiu acessar as informações que constavam nos autos, do qual se beneficiou" (2017, p. 2-3).
} 
época com 97 anos, que vivia em uma grota no Córrego Buriti, na localidade denominada São Lourenço) ${ }^{22}$ em entrevista concedida a COSTA.

Ainda no que tange ao processo de privatização das terras na referida região, constatou-se que, em somente treze processos judiciais atribuiu-se o status de propriedade privada a um milhão, sessenta mil e oitocentos e sessenta e cinco hectares e oitenta e três ares de terra (1.060.865,83 hectares de terra) (COSTA, 2017, p. 2-3). Não é possível sequer mensurar quantos posseiros foram alijados das terras que ocupavam por esses treze beneficiários a quem foram atribuídas as propriedades.

Há histórias também como a do Sr. Adão José Alves e de outros moradores da comunidade "Córrego dos Bois", área também inserida em processos judiciais de divisão e demarcação na década de 1930. Narra este que foi conduzido ao Cartório de Grão Mogol por um grileiro para a venda de 70ha, por $\mathrm{R} \$ 9.000,00$ (nove mil reais), de terras que seriam destinadas a uma reserva ambiental, mas, que, na verdade, a empresa registrou, sem o seu conhecimento, uma venda de 723ha, a qual atribuiu o valor de $\mathrm{R} \$ 400.000,00$ (quatrocentos mil reais) (COSTA, 2017, p. 6).

Esse processo geopolítico de apropriação privada das terras devolutas implicou uma transformação degradante da condição humana. Os camponeses que até então usufruíam de uma abundância de terras livres de modo sustentável passaram a ser confinados em grotas específicas. As chapadas foram tomadas por eucaliptos e carvoeiras e os camponeses constituíram também a mão-de-obra empregada, em situações precárias de trabalho (COSTA, 2017, p. 7-8).

Nota-se, pois, que a herança deixada pela política colonizadora se propagou por longa data no processo de ocupação do território, com a prevalência de privilégios que visavam a satisfação de interesses dos mais fortes, inseridos no sistema de produção capitalista, com a propagação de inúmeros conflitos em que os

22 "Essa família teve as terras invadidas pela empresa FOSCALMA S/A Comercial Exportadora, pelo qual tem sido "recantiladas". Dona Vicença e seus filhos recordam os tempos da fartura, quando havia muitos peixes nos córregos, quando criavam cerca de 20 cabeças de gado na solta, quando havia muitos frutos e caças no cerrado, plantavam seus roçados e cultivavam as hortas produziam uma das melhores farinhas de mandioca vendidas na feria de Grão Mogol, cultivavam variedades de arroz no brejo, na atualidade, totalmente seco, consequência dos danos causados pelo monocultivo de madeira. Eles contam que na década de 1960 quando chegaram as firmas interessadas em suas terras, chegou uma senhora vinda de fora com uma mala preta, estava cheia de dinheiro, ela abriu e ofereceu à Dona Vicença em troca de suas terras. A geraizeira recusou a oferta preocupada em garantir terra de morada para os filhos. Não demorou e as máquinas chegaram destruindo o cerrado, invadindo as terras dessa família "arrebentando tudo com as máquinas". Impedindo um cultivo, "você roçava um matinho e eles já vinham impedir” $(2017$, p. 5). 
mais fracos - que geralmente são os primeiros ocupantes da terra e que deveriam, em respeito a essa condição, serem considerados os legítimos proprietários das terras devolutas - são alijados de sua única fonte de subsistência.

\section{CONSIDERAÇÕES FINAIS}

A caótica situação fundiária brasileira é resultado, em um primeiro momento, da política colonizadora que foi implantada no Brasil, em que o objetivo maior sempre foi promover o rápido povoamento, evitando-se que sobreviessem conflitos por definições de fronteiras, principalmente com os países de língua espanhola.

E não se podia esperar conduta diferente do colonizador que, para acelerar o processo e cumprir o seu mister de dominar a vastidão de terras descobertas, promoveu a concessão de sesmarias, que constituíram o embrião para a formação dos grandes latifúndios.

Logicamente, não possuindo a Coroa portuguesa recursos para promover uma ocupação ordenada e centralizada de um território tão amplo, alternativa outra não haveria senão incentivar as ocupações e investimentos do capital privados nas terras descobertas. E, inclusive, não se pode desconsiderar a impossibilidade de se ter priorizado a criação de minifúndios, com a distribuição igualitária da terra, porque não haviam sequer interessados suficientes, pelo menos à época da colonização, em promover esse povoamento.

Outro grande percalço surgido se trata de, face à maneira em que se deu a colonização, não ter sido possível o cumprimento fiel das legislações - que, inclusive, demonstram a acuidade jurídica do legislador, com o intuito de sempre proteger a posse com cultura efetiva e a morada habitual, conforme se pode colher da disciplina das terras devolutas e dos processos discriminatórios.

Como a ocupação, com o passar dos anos, foi desregrada e como jamais foi possível promover a discriminação e arrecadação das terras devolutas de forma eficiente, os processos previstos em lei, para o trato da questão, foram sabotados pela grande quantidade de conflitos envolvendo as terras, pela inexistência de cadastros e controles das propriedades regularmente constituídas e pelas artimanhas engendradas pelas elites agrárias, para o reconhecimento de propriedades em seus nomes. 
É no curso das discriminações - que deveriam representar a forma de se buscar a justa ordenação do território - que se agravam os conflitos, muitas vezes sangrentos, e que se evidencia a mais grave violação dos direitos e garantias fundamentais dos indivíduos.

\section{REFERÊNCIAS}

ALMEIDA, É. C. de A; SARDAGNA, C. D. O parcelamento do imóvel rural via fração mínima de parcelamento frente à função social da propriedade. Revista de Informação Legislativa, Brasília, v. 37, n. 146, p. 209-216, 2000. Disponível em: $<$ http://www2.senado.leg.br/bdsf/bitstream/handle/id/592/r146-16. pdf? sequence=4>. Acesso em 03 dez. 2018.

ALVARENGA, Octavio Mello. Teoria e prática do direito agrário. Rio de Janeiro: Consagra, 1979, 302p.

ALVES, Fábio. Direito Agrário: política fundiária no Brasil. Belo Horizonte: Del Rey, 1995. 271p.

BRASIL. Lei oㅜ 601, de 18 de setembro de 1850. Dispõe sobre as terras devolutas do Império. Secretaria de Estado dos Negocios do Imperio, 20 set. de 1850. Disponível em <http://www.planalto.gov.br/CCIVIL_03/LEIS/L0601-1850.htm>. Acesso em: 10 dez. 2018.

BRASIL. Decreto № 1.318, de 30 de janeiro de 1854. Manda executar a Lei oㅡ 601, de 18 de setembro de 1850. Coleção das Leis Império do Brasil, 1854, Tomo XV, Parte 2, p. 10. Disponível em <http://www.planalto.gov.br/ccivil_03/decreto/18511899/D1318.htm>. Acesso em: 10 dez. 2018.

BRASIL. Decreto no 451-B, de 31 de maio de 1890. Estabelece o registro e transmissão de immoveis pelo systema Torrens. CLBR, Rio de Janeiro, 3 mai. 1890. Disponível em: < http://www2.camara.leg.br/legin/fed/decret/1824-1899/decreto-451b-31-maio-1890-516631-publicacaooriginal-1-pe.html>. Acesso em 27 dez. 2018.

BRASIL. Decreto oㅜ 720, de 5 de setembro de 1890. Manda executar o regulamento sobre divisão e demarcação das terras particulares. CLBR, Rio de Janeiro, 5 de set. de 1890. Disponível em: <http://www2.camara.leg.br/legin/fed/decret/18241899/decreto-720-5-setembro-1890-518002-publicacaooriginal-1-pe.html>. Acesso em 27 dez. 2018. 
BRASIL. Decreto no 955-A, de 05 de novembro de 1890. Promulga o regulamento para execução do decreto n. $451 \mathrm{~B}$, de 31 de maio do corrente anno, que estabeleceu o registro e transmissão de immoveis pelo systema Torrens. CLBR, Rio de Janeiro, 05 nov.1890. Disponível em:

<http://www.planalto.gov.br/ccivil_03/decreto/1851-1899/D00955-A.html>. Acesso em 27 dez. 2018.

BRASIL. Constituição da República dos Estados Unidos do Brasil, de 24 de fevereiro de 1891. Nós, os representantes do povo brasileiro, reunidos em Congresso Constituinte, para organizar um regime livre e democrático, estabelecemos, decretamos e promulgamos a seguinte....Diário Oficial da União, Rio de Janeiro, 24 fev. 1891. Disponível em <http://www.planalto.gov.br/ccivil_03/Constituicao/Constituicao91.htm>. Acesso em 03 dez. 2018

BRASIL. Lei n 3.071, de 1ํ de janeiro de 1916. Código Civil dos Estados Unidos do Brasil. Diário Oficial da União, Rio de Janeiro, 05 jan. 1916. Disponível em: < http://www.planalto.gov.br/ccivil_03/leis/L3071.htm>. Acesso em: 02 dez. 2018.

BRASIL. Constituição da República dos Estados Unidos do Brasil, de 16 de julho de 1934. Nós, os representantes do povo brasileiro, pondo a nossa confiança em Deus, reunidos em Assembléia Nacional Constituinte para organizar um regime democrático, que assegure à Nação a unidade....Diário Oficial da União, Rio de Janeiro, 16 jul. 1934. Disponível em <http://www.planalto.gov.br/ccivil_03/Constituicao/Constituicao34.htm>. Acesso em 03 dez. 2018

BRASIL. Decreto-Lei no 9.760, de 5 de setembro de 1946. Dispõe sobre os bens imóveis da União e dá outras providências. Diário Oficial da União, Rio de Janeiro, 06 set. 1946. Disponível em: <http://www.planalto.gov.br/ccivil_03/DecretoLei/Del9760.htm>. Acesso em 11 dez. 2018.

BRASIL. Constituição dos Estados Unidos do Brasil, de 18 de setembro de 1946. Nós, os representantes do povo brasileiro, reunidos, sob a proteção de Deus, em Assembléia Constituinte para organizar um regime democrático, decretamos e promulgamos o seguinte... Diário Oficial da União, Rio de Janeiro, 19 set. 1946. Disponível em <http://www.planalto.gov.br/ccivil_03/Constituicao/Constituicao46.htm>. Acesso em 03 dez. 2018.

BRASIL. Lei no 3.081, de 22 de dezembro de 1956. Regula o processo nas ações discriminatórias de terras públicas. Diário Oficial da União, Rio de Janeiro, 26 dez. 1956. Disponível em: < http://www.planalto.gov.br/ccivil_03/LEIS/19501969/L3081.htm>. Acesso em 11 dez. 2018. 
BRASIL. Lei no 4.504, de 30 de novembro de 1964. Dispõe sobre o Estatuto da Terra, e dá outras providências. Diário Oficial da União, Brasília, 30 nov. 1964. Disponível em: <http://www.planalto.gov.br/ccivil_03/LEIS/1950-1969/L3081.htm>. Acesso em $11 \mathrm{dez} .2018$.

BRASIL. Constituição da República Federativa do Brasil, de 24 de janeiro de 1967. O Congresso Nacional, invocando a proteção de Deus, decreta e promulga a seguinte...Diário Oficial da União, Brasília, 24 jan. 1967. Disponível em <http://www.planalto.gov.br/ccivil_03/Constituicao/Constituica067.htm>. Acesso em 03 dez. 2018.

BRASIL. Lei 6.383, de 7 de dezembro de 1976. Dispõe sobre o Processo Discriminatório de Terras Devolutas da União, e dá outras Providências. Diário Oficial da União, Brasília, 09 dez. 1976. Disponível em: <http://www.planalto.gov.br/ccivil_03/LEIS/L6383.htm>. Acesso em 10 dez. 2018.

BRASIL. Constituição da República Federativa do Brasil de 1988. Nós Representantes do povo brasileiro, reunidos em Assembleia Nacional Constituinte para instituir um Estado Democrático, destinado a assegurar o exercício dos direitos sociais e individuais... Diário Oficial da União, Brasília, 05 out. 1988. Disponível em: <http://www.planalto.gov.br/ccivil_03/constituicao/constituicao.htm>. Acesso em: 02 nov. 2018.

CYSNEIROS, Vicente Cavalcanti. Posse de bens públicos. Revista de Direito Agrário. Ministério da Agricultura - INCRA. Brasília. Ano 1, no 2, p. 8-16, jul./set. 1973.

COSTA, Hélio Roberto Novoa da. Discriminação de Terras Devolutas. São Paulo: Livraria e Editora Universitária de Direito, 2000, 170p.

COSTA, Sandra Helena Gonçalves. Recantilados entre o direito e o rentismo: grilagem judicial e a formação da propriedade privada da terra no norte de Minas Gerais. 2017. 707f. Tese (Doutorado) - Programa de Pós-Graduação em Direito, Universidade de São Paulo - USP, São Paulo, 2017. Disponível em:

<http://www.teses.usp.br/teses/disponiveis/8/8136/tde-09012018-154704/pt-br.php>. Acesso em: 05 dez. 2018.

FRANÇA, Vladimir da Rocha. Perfil constitucional da função social da propriedade. Revista de informação legislativa, Brasília, v. 36, n. 141, p. 9-21, jan./mar. 1999. Disponível em: <http://www2.senado.leg.br/bdsf/bitstream/handle/id/446/r14102.pdf? sequence=4>. Acesso em 03 dez. 2018. 
GARCIA, Paulo. Terras devolutas. Belo Horizonte: Oscar Nicolai, 1958, 270p.

GRAZIANO, Eduardo; GRAZIANO NETO, Francisco. As condições da reprodução camponesa no Vale do Jequitinhonha. Perspectivas: revista de ciências sociais. Universidade Estadual Paulista - UNESP, São Paulo, p. 85-100, 1983. Disponível em: <https://repositorio.unesp.br/bitstream/handle/11449/108226/ISSN1984-02411983-6-85-100.pdf?sequence=1\&isAllowed=y>. Acesso em: 05 dez. 2018.

JUNQUEIRA, Messias. Justificativa e ante projeto da Lei de Terras. São Paulo: Revista dos Tribunais, 1942.

As terras devolutas na reforma agrária. São Paulo: Revista dos Tribunais, 1976.

LACERDA, Linhares de. Tratado das Terras do Brasil. Rio de Janeiro: Alba, 1960.

LIMA, Ruy Cirne. Pequena história territorial no Brasil: sesmarias e terras devolutas. 2 ed. Porto Alegre: Sulina, 1954, 112p.

O Instituto das Terras Devolutas. São Paulo: Lael, 1976.

MAIA, Altir de Souza. Discriminação de Terras. Brasília: Fundação Petrônio Portella, 1982.

MACHADO, Edna Moreira de Lima. Discriminação de terras devolutas: tarefa inconclusa, desde o Brasil imperial, em prejuízo para a reforma agrária. 2002. $172 f$. Dissertação (Mestrado). Programa de Pós-Graduação em Direito, Universidade Federal de Pernambuco. Brasília, 2002. Disponível em: $<$ https://repositorio.ufpe.br/bitstream/123456789/4397/1/arquivo5568_1.pdf>. Acesso em: 10 dez. 2018.

MALINA, Léa Lameirinhas. A territorialização do monopólio no setor celulísticopapeleiro: a atuação da Veracel Celulose no extremo sul da Bahia. 2013. 359f. Dissertação (Metrado). Programa de Pós-Graduação em Direito, Universidade de São Paulo - USP, São Paulo, 2017. Disponível em: <http://www.teses.usp.br/teses/disponiveis/8/8136/tde-18022014-152910/pt-br.php>. Acesso em: 05 dez. 2018. 
MARCÍLIO, Alvaro. O problema das terras devolutas e suas matas no estado de Minas Gerais. Belo Horizonte: Santa Maria, 1961.

PRIETO, Gustavo Francisco Teixeira. Rentismo à brasileira, uma via de desenvolvimento capitalista: grilagem, produção do capital e formação da propriedade privada da terra. 2016. 743f. Tese (Doutorado) - Programa de PósGraduação em Direito, Universidade de São Paulo - USP, São Paulo, 2016. Disponível em: < http://www.teses.usp.br/teses/disponiveis/8/8136/tde-27032017104718/pt-br.php>. Acesso em 06 dez. 2018.

SCHEID, Cíntia Maria. O princípio da função social da propriedade e sua repercussão na evolução da regularização fundiária urbana no ordenamento jurídico brasileiro. Revista de Direito Imobiliário, São Paulo, v. 83, ano 40, p. 423-454, dez2017.

SILVA, Angela. Terras Devolutas. Coleção doutrinas essenciais: direito registral. v. 3, 2 ed. São Paulo: Editora Revista dos Tribunais, p. 56-114, 1984.

SOUSA SOBRINHO, José de. O camponês geraizeiro no Oeste da Bahia: as terras de uso comum e a propriedade capitalista da terra. 2012.436f. Tese (Doutorado) Programa de Pós-Graduação em Direito, Universidade de São Paulo USP, São Paulo, 2017. Disponível em: <http://www.teses.usp.br/teses/disponiveis/8/8136/tde-06032013-093947/pt-br.php>. Acesso em: 05 dez. 2018.

OLIVEIRA, Ariovaldo Umbelino de. A política de reforma agrária no Brasil. In: SYDOW, E. M.; MENDONÇA, M.L. (Org.) Direitos Humanos no Brasil 2009. São Paulo: Rede Social de Justiça e Direitos Humanos, p. 27-38, 2009.

PEREIRA, José Edgard Penna Amorim. Perfis constitucionais das terras devolutas. Belo Horizonte: Del Rey, 2003. 256p.

SAQUET, Marcos Aurélio. Abordagens e concepções de território. 4 ed. São Paulo: Outras Expressões, 2015.

VARELA, Laura Beck. Das sesmarias à propriedade moderna: um estudo de história do direito brasileiro. Rio de Janeiro: Renovar, 2005, 278p. 